\title{
Mitigation of Food Crisis and Increasing Productivity of Rice Fields for Communities Around the Taman Asoka Asri Housing Amid the Covid-19 Pandemic
}

\author{
Muhdi $^{1 *}$, Diana Sofia Hanafiah ${ }^{2}$, Onrizal ${ }^{1}$, Samsuri ${ }^{1}$, Ridwanti Batubara ${ }^{1}$ \\ ${ }^{1}$ Faculty of Forestry, Universitas Sumatera Utara \\ ${ }^{2}$ Faculty of Agriculture, Universitas Sumatera Utara \\ *Email: muhdisyehamad@yahoo.com
}

\begin{abstract}
Currently, the global economy is shaken by the Covid-19 pandemic. Based on the results of the preliminary study at the partner's location, it has economic limitations, including the availability of food supply which has an impact on non-productive communities, including farmers and tenant farmers around Taman Asoka Asri Housing, Tanjung Selamet, Medan Tuntungan, Medan, North Sumatra. All activities that will be carried out by the USU PPM proposing team will of course follow and pay attention to the Covid-19 prevention protocol. The implementation of this community service is carried out in the vicinity of the Taman Asoka Asri Housing, so the activity plan that will be carried out is the use of rice fields for farmers and cultivators in the environment around the Taman Asoka Asri Housing. The area of paddy rice fields managed by smallholders around the Taman Asoka Asri Complex, Tanjung Selamet, Medan Tuntung, Medan an average of 2,725 m² (0.2725 ha). Rice field management areas that have been successfully managed by partners have become productive areas that can increase income and profits for smallholders.
\end{abstract}

Keyword: Covid-19 pandemic, productive land, rice fields, farmers

\begin{abstract}
Abstrak
Saat ini, perekonomian global sedang diguncang oleh pandemi Covid-19. Berdasarkan hasil studi pendahuluan di lokasi mitra memiliki keterbatasan ekonomi, diantaranya adalah ketersediaan pasokan pangan berdampak pada masyarakat non produktif termasuk petani dan petani penggarap di sekitar Perumahan Taman Asoka Asri, Tanjung Selamet, Medan Tuntungan, Medan, Sumatera Utara. Semua kegiatan yang akan dilakukan oleh tim pengusul PPM USU tentunya akan mengikuti dan memperhatikan protokol pencegahan Covid-19. Pelaksanaan pengabdian masyarakat ini dilakukan di sekitar Perumahan Taman Asoka Asri, kegiatan yang dilakukan adalah pemanfaatan lahan persawahan terlantar dan tidak produktif menjadi areal persawahan padi yang dimanfaatkan oleh petani penggarap di lingkungan sekitar Perumahan Taman Asoka Asri. Luas areal persawahan yang dikelola oleh petani rakyat di sekitar Kompleks Taman Asoka Asri, Tanjung Selamet, Medan Tuntung, Medan rata-rata seluas $2.725 \mathrm{~m} 2$ (0.2725 ha). Areal pengelolaan sawah yang telah berhasil dikelola oleh mitra menjadi areal produktif mampu meningkatkan pendapatan dan keuntungan bagi petani penggarap.
\end{abstract}

Kata Kunci: Pandemi Covid-19, lahan produktif, sawah, petani

\section{PENDAHULUAN}

Saat ini kondisi perekonomian global terguncang akibat wabah pandemi Covid-19. Hal ini juga berdampak terhadap masyarakat Indonesia (Nasution et al., 2020). Kekhawatiran ini diungkapkan Presiden Republik Indonesia, Ir. H. Joko Widodo. Pemerintah mengeluarkan kebijakan ketersediaan bahan-bahan pokok, menjaga daya beli masyarakat dan memberikan bantuan bahan pokok yang amat dibutuhkan di tengah kebijakan tanggap darurat Covid-19 ini (Adi, 2020).

Sejalan dengan hal tersebut, kehawatiran pemerintah terhadap bahan-bahan pokok masyarakat diantarannya krisis pangan termasuk beras sangat penting. Sebagai kebutuhan 
masyarakat, Tim Pengusul melihat kondisi masyarakat sekitar begitu mengkhawatirkan, terutama masyarakat petani dan petani penggarap di sekitar Perumahan Taman Asoka Asri. Lahan sawah ini sangat penting dan strategis untuk mengatasi krisis pangan bagi masyarakat sekitar. Sasaran program pengabdian ini adalah lahan persawahan di sekitar Perumahan Taman Asoka Asri, Jalan Flamboyan Raya, Tanjung Slamet, Medan Tuntungan Kota Medan - 20135.

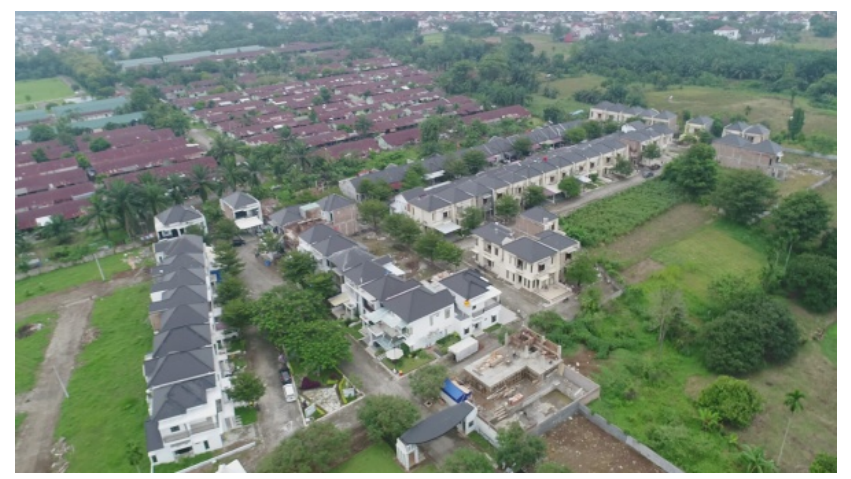

Gambar 1. Lokasi mitra, Perumahan Taman Asoka Asri

Mitra, merupakan kelompok petani dan petani penggarap. Petani penggarap tidak mempunyai lahan sawah, mereka menanam padi atas dasar bagi-hasil dengan pemilik lahan. Petani penggarap merupakan petani padi aktif, karena ia mengerjakan usaha tani padi dari sejak membuat persemaian, olah tanah, tanam, pemupukan dan seterusnya hingga panen. Bahkan, petani penggarap membeli benih, pupuk, pestisida, dan membayar ongkos pengolahan tanah dengan traktor dan membayar tenaga kerja tanam, penyiangan, dan panen. Faktor yang membedakan petani penggarap dengan petani padi biasa adalah mereka tidak memiliki lahan sawah yang mereka garap.

Selain itu, jika kegiatan program pengabdian masyarakat ini sangat membantu mitra dan sangat antusias agar tim pengusul PPM USU bisa berkontribusi dalam menangani permasalahanpermasalahan yang dihadapi mitra terutama dalam mitigasi krisis pangan dan peningkatan prodiktivitas lahan sawah di sekitar Komplek Taman Asoka Asri.

Keadaan mitra saat ini mengalami keterpurukan ekonomi dalam memenuhi kebutuhan pokok. Mitra juag mitra menghadapai keterbatasan dalam mengakses kebutuhan pokok dengan harga yang terjangkau. Selain itu kenaikan harga barang, termasuk bahan pokok sebagai dampak perlambatan ekonomi global akiabt wabah Covid-19. Oleh karena itu, kegiatan yang mengoptimalkan ketersediaan dan akses terhadap kebutuhan pokok pangan dalam mengatasi dampak penyebaran virus corona atau Covid-19 yang berlangsung relatif cepat dan mempengaruhi kondisi perekonomian nasional menjadi salah satu prioritas utama.

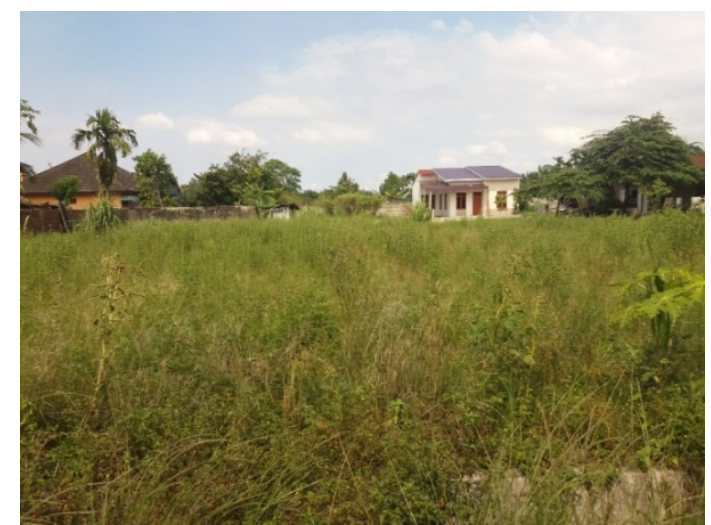

a. Sawah terlantar

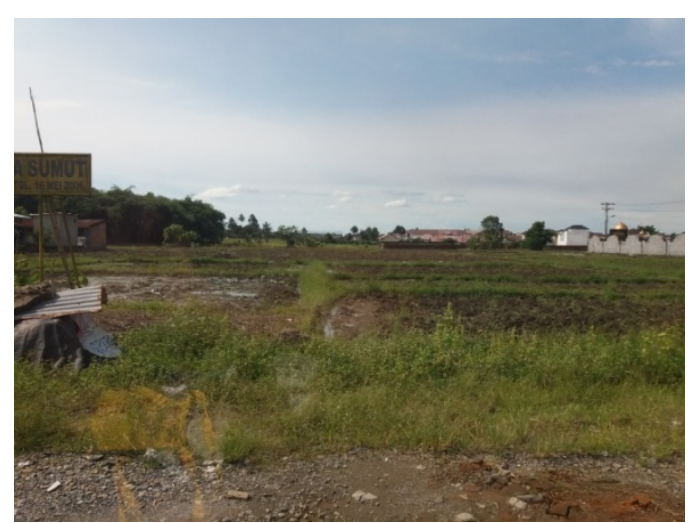

b. Sawah tidak produktif

Gambar 2. Kondisi Lahan Sawah Disekitar Perumahan Taman Asoka Asri 
Muhdi et al. Mitigation of food crisis and increasing productivity of rice fields

Berdasarkan hasil studi pendahuluan di lokasi mitra memiliki keterbatasan ekonomi, diantaranya adalah ketersediaan pasokan pangan berdampak pada masyarakat non produktif termasuk petani dan petani penggarap di sekitar Perumahan Taman Asoka Asri. Ketersediaan pasokan pangan pokok untuk menghadapi Bencana Nasional Covid-19. Pada sisi lain, mitra mengalami keterpurukan karena terbatasnya teknologi dalam pengelolaan lahan sawah mereka. Padahal komuditas padi sawah sangat potensial karena merupakan bahan makanan pokok dan memiliki pangsa pengeluaran pangan kedua terbesar, yaitu sebesar 17,28 \%. Ironisnya, produksi beras hingga saat ini masih belum mengalami kemajuan yang signifikan.

Kondisi persawahan yang terlantar dan atau tidak produktif karena petani dan petani penggarap sangat tergantung kepada musim, bukan sawah irigasi. Petani dan petani penggarap di sekitar Perumahan Taman Asoka Asri mennyatakan bahwa lahan persawahan padi belum memiliki irigasi permanen. Sebab, jika hal itu terjadi, bisa berakibat petani gagal panen. Kalau areal persawahan sudah tergenang air yang melebihi kebutuhannya, tentu akan berdampak pada pertanaman padi sawah. Setidaknya, padi akan terserang hama.

\section{METODE PELAKSANAAN}

Pelaksanaan kegiatan yang akan dilakukan oleh tim pengusul PPM USU tentunya akan mengikuti dan memperhatikan protokol pencegahan Covid-19 saat dan selama beraktivitas ditengah lapangan. Tim pengusul PPM USU akan melakukan kegiatan berdasarkan permasalahan masyarakat khususnya petani dan petani penggarap di sekitar Perumahan Taman Asoka Asri adalah pemanfaatan lahan sawah bagi petani dan petani penggarap di lingkungan sekitar Perumahan taman Asoka Asri.

Pengelolaan Tanaman Terpadu (PTT) padi sawah adalah untuk meningkatkan pendapatan petani melalui penerapan teknologi yang cocok untuk kondisi setempat yang dapat meningkatkan hasil gabah dan mutu beras serta menjaga kelestarian lingkungan. Diharapkan kegiatan program pengabdian oleh tim pengusul nantinya memberikan manfaat yang besar bagi mitra yakni petani dan petani penggarap di sekitar Perumahan Taman Asoka Asri.

Semua aktivitas pelaksanaan kegiatan yang akan dilakukan oleh tim pengusul PPM USU tentunya akan mengikuti dan memperhatikan protokol pencegahan Covid-19. Pelaksanaan pengabdian pada masyarakat ini akan dilakukan di sekitar Perumahan Taman Asoka Asri, maka rencana kegiatan yang akan dilakukan adalah pemanfaatan lahan sawah bagi petani dan petani penggarap di lingkungan sekitar Perumahan taman Asoka Asri. Pengelolaan tanaman terpadu padi sawah di areal sekitar perumahan Taman Asoka Asri, peserta yang ditargetkan meliputi petani dan petani penggarap.

Upaya peningkatan produktivitas itu sendiri peran dari petani juga diperlukan. Pendidikan dan lama berusahatani para petani akan mempengaruhi seberapa besar informasi yang didapatkannya (Hardjowigeno dan Rayes, 2005). Tujuan dari kegiatan ini yaitu untuk memberikan memberikan pengetahuan kepada lahan sawah dalam meningkatkan produktivitas lahannya dan juga pendapatan petani dan petani penggarap di sekitar Perumahan Taman Asoka Asri. Selanjutnya tim pengusul juga membuat demplot di lokasi lahan sawah Sekitar. Perumahan Taman Asoka Asri.

Adanya ancaman serangan hama pengganggu yang dapat mempengaruhi produktifitas tanaman padi. Salah satu hama yang mengganggu tanaman padi adalah hama burung. Yang paling sering menyerang tanaman padi dalam jumlah banyak ialah burung pipit yang biasanya terbang dalam kawanan. Nama lain dari burung pipit ialah burung gelatik, burung emprit, burung peking dan burung gereja. Sedang jenis burung lain yang juga menyerang tanaman padi namun dalam jumlah kecil ialah burung manyar. Menggunakan jaring untuk melindungi tanaman padi merupakan cara yang sangat efisien karena bukan hanya akan menakuti burung namun juga bisa menangkap burung tersebut. Caranya adalah membentangkan beberapa baris jaring memanjang diatas tanaman padi. Pada pelaksanaan pengabdian ini, tim PPM USU direncanakan akan memberikan jarring untuk melindungi hama burung. 


\section{HASIL DAN PEMBAHASAN}

Kegiatan pengabdian telah dilakukan oleh tim pengabdian dengan mengikuti dan memperhatikan protokol pencegahan Covid-19 saat dan selama beraktivitas ditengah lapangan. Tim pengabdian telah melakukan kegiatan di sekitar Perumahan Taman Asoka Asri adalah dengan pemanfaatan lahan sawah bagi petani dan petani penggarap di lingkungan sekitar Perumahan taman Asoka Asri.

\section{Karakteristik Petani Responden}

Kelompok petani penggarap sebagai mitra tim pengabdian pada masyarakat USU merupakan petani yang memanfaatkan lahan sawah di sekitar perumahan Taman Asoka Asri. Petani penggarap yang berpartisipasi dalam program ini adalah sebanyak 8 (delapan) orang.

Beberapa karakteristik peserta petani penggarap yang dianggap penting meliputi luas lahan, jenis kelamin, pendidikan, dan tanggungan. Pendidikan adalah sarana belajar yang selanjutnya memberikan arahan yang lebih menguntungkan menuju pengaplikasian ilmu pertanian yang lebih modern. Karakteristik tersebut dianggap penting karena selain mempengaruhi pelaksanaan usahatani terutama dalam pelaksanaan teknik budidaya yang nantinya akan berpengaruh terhadap produksi, juga diperlukan untuk melihat bagaimana pengaruhnya terhadap produktivitas tanaman padi sawah (Indraningsih, 2020). Untuk lebih jelasnya mengenai keadaan rata-rata karakteristik petani padi sawah dapat dilihat pada Tabel 3.1.

\begin{tabular}{lll}
\hline No. & Karakteristik & Rata-rata \\
\hline 1 & Jenis Kelamin (Laki-laki) (\%) & $12,5 \%$ \\
2 & Pendidikan (tahun) & 8,625 \\
3 & Jumlah Tanggungan (jiwa) & 3,25 \\
4 & Luas lahan (ha) & 0,2725 \\
\hline
\end{tabular}

Tabel 3.1. Karakteristik petani penggarap

Tabel 3.1. menunjukkan bahwa petani penggarap sebagian besar yang mengelola sawah adalah berjenis kelamin perempuan yakni sebanyak 87,5 \%. Petani penggarap dilakukan oleh perempuan karena dianggap sebagi pekerjaan sampingan yang membantu pendapatan keluarga. Tingkat pendidikan petani penggarap adalah 8,625 tahun. Ini menunjukkan bah tingkat pendidikan petani penggrap di sekitar lokasi pengabdian pada masyarakat USU masih rendah. Rendahnya tingkat pendidikan yang diterima para petani penggarap akan mempengaruhi produktivitas pengelolaan sawahnya. Hal ini disebabkan pendidikan yang rendah menyebakan kemampuan daya serap petani terhadap perkembangan teknologi dan inovasi baru menjadi rendah, sehingga petani penggarap dalam mengikuti perkembangan ipteks menjadi terlambat dan membutuhkan masa waktu yang lebih lama dan menerima pengetahuan dan inovsi baru di bidang pertanian.

Tabel 3.1. menunjukkan bahwa jumlah tanggungan keluarga petani penggarap di areal persawahan Komplek Taman Asoka Asri sebanyak 3,25 orang. Adapun jumlah tanggungan keluarga, sangat mempengaruhi perekonomian keluarga. Jumlah tanggungan keluarga petani penggarap sebagai mitra pengabdian pada masyarakat USU mempengaruhi pendapatan dan pengeluaran keluarga. Semakin sedikit jumlah tanggungandalam suatu keluarga, cenderung pengeluaran keluarga petani penggarap akan berkurang dan sebaliknya semakin banyak jumlah tanggungan dalam suatu keluarga cenderung biaya yang dikelaurkan akan semakin besar. Akan tetapi, besarnya tanggungan atau jumlah anggota keluarga juga membantu dalam menambah pendapatan keluarga berupa penambahan income keluarga sehingga biaya yang dikeluarkan keluarga petani penggarap menjadi lebih rendah. Namun, jumlah keluarga juga merupakan aset yang penting dalam membantu kegiatan petani karena akan menambah pencurahan tenaga kerja keluarga, sehingga biaya produksi yang harus dikeluarkan oleh petani akan lebih kecil.

\section{Luas Areal Persawahan yang Digarap Petani Penggarap}

Luasan areal persawahan tanaman padai yang dikelola oleh petani penggarap di sekitar Komplek Taman Asoka Asri, Tanjung Selamet, Medan Tuntungan, Medan rata-rata seluas $2725 \mathrm{~m}^{2}$ 
(0,2725 ha). Luas areal terkecil yang dikelola oleh keluarga petani penggarap seluas $1000 \mathrm{~m}^{2}$ (0,1 ha) dan yang terluas seluas $4.500 \mathrm{~m}^{2}(0,45 \mathrm{ha})$. Luasan lahan persawahan mempengaruhi pendapatan petani penggarap. Areal pengelolaan persawahan padai adalah faktor produksi yang dapat meningkatkan pendapatan dan keuntungan bagi mitra.

Petani penggarap di areal persawahan Komplek Taman Asoka Asri luas lahan yang digarap rata-rata sebesar 0,2725 ha. Apabila dilihat dari luas lahan yang digarap oleh mitra maka sangat potensial untuk meningkatkan pendapatan petani penggarap ini. Oleh karena itu keberlanjutan pembinaan dan pelaksanaan pengabdian pada masyarakat USU di lokasi mitra perlu ditingkatkan, karena hal ini akan sulit terlaksana jika tanpa perhatian dari pihak yang terkait. Mitra sangat merasa terbantu dengan adanya kegiatan pengabdian pada masyarakt USU dalam menambah ipteks dan berharap kedepannya mereka dapat mendapatkan program-program baru yang mampu menambah pendapatan keluarga termasuk berperan untuk meningkatkan pengetahuan, sikap dan keterampilan para keluarga petani penggarap di areal persawahan Komplek Taman Asoka Asri, Tanjung Selamet, Medan Tuntungan, Medan.

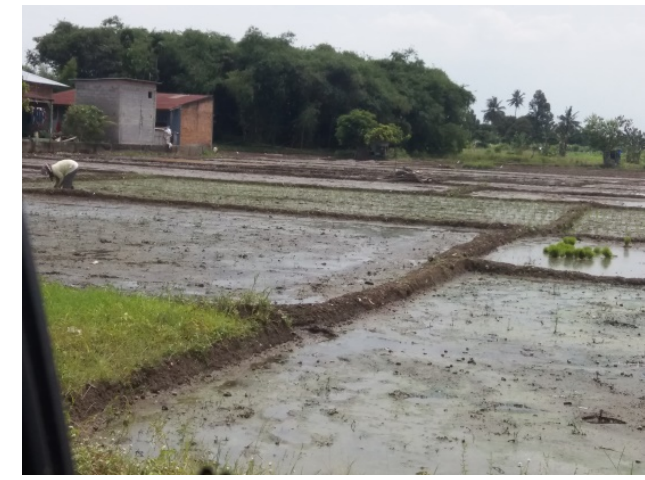

a. Penanaman

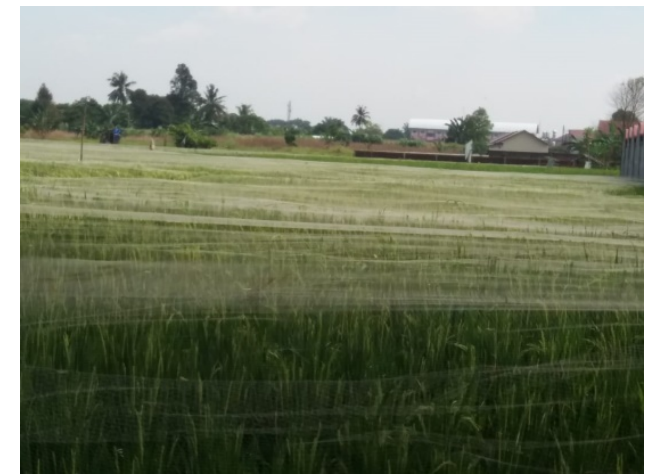

b. Pemasangan jaring paranet

Gambar 3.1. Persawahan padi yang dikelolan petani penggarap

\section{Bantuan Faktor Produksi bagi Petani Penggarap}

Tim pengabdian memberikan paket bantuan faktor produksi kepada petani penggarap melalui 2 tahapan. Pada Tahap I, tim pengabdian bantuan memberikan bantuan benih padi Inpari-32 sebanyak 8 paket (karung), jaring para net putih ukuran $12 \mathrm{~m}$ x 30 m sebanyak 5 paket (karung) dan pupuk NPK 2 zak (karung). Selanjutnya seiring dengan masa pandemic covid-19, tim pengabdian juga memberikan bantuan masker bagi para peserta petani dan petani penggarap.

Bantuan pada Tahap 2, tim pengabdian USU memberikan bantuan berupa pupuk NPK 1 zak (karung) dan pupuk urea 1 zak (karung), jaring para net ukuran 12 x $30 \mathrm{~m}^{2}$ sebanyak 5 paket dan fungisida. Selain itu tim pengabdian pada masyarakat USU pada bantuan ke-2 ini juga memberikan paket masker kepada mitra.

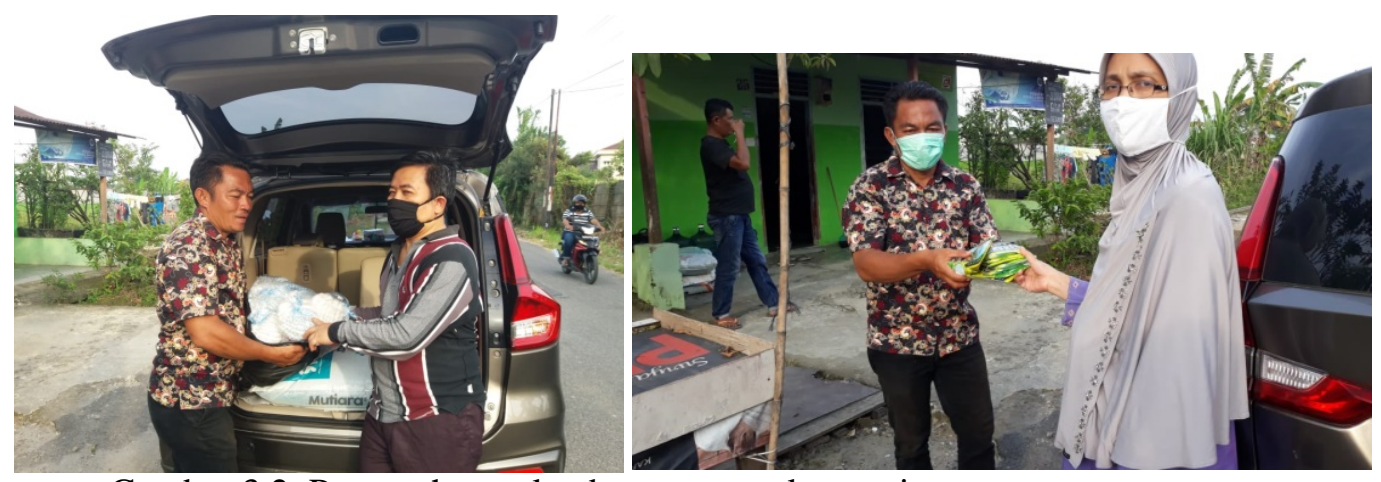

Gambar 3.2. Penyerahan paket bantuan untuk petani penggarap

Selama kegiatan berlangsung mitra sangat antusias hal ini ditunjukkan dengan hadirnya semua petani penggarap di areal pengabdian, dimana terdapat 8 orang anggota petani penggarap yang 
Muhdi et al. Mitigation of food crisis and increasing productivity of rice fields

menjadi mitra pengabdian ini. Pada akhir sesi penyuluhan, petani penggarap sangat mengharapkan kegiatan ini dapat dilanjutkan. Kesadaran petani dan petani penggarap dalam memanfaatkan lahan persawahan untuk meningkatkan hasil dan pendapatan keluarga.

\section{KESIMPULAN (}

Tim pengabdian telah melakukan kegiatan di sekitar Perumahan Taman Asoka Asri adalah dengan pemanfaatan lahan sawah bagi petani dan petani penggarap di lingkungan sekitar Perumahan taman Asoka Asri. Selama kegiatan berlangsung mitra sangat antusias hal ini ditunjukkan dengan hadirnya semua petani penggarap di areal pengabdian, dimana terdapat 8 (delapan) orang petani penggarap yang menjadi mitra pengabdian ini. Pada akhir sesi penyuluhan, petani penggarap sangat mengarapkan kegiatan ini dapat dilanjutkan secara berkesinambungan.

\section{UCAPAN TERIMAKASIH}

Terima kasih kepada Rektor Universitas Sumatera Utara yang telah mendanai penelitian ini. Terima kasih kepada Ketua Lembaga Pengabdian kepada Masyarakat yang telah mefasilitasi program pengabdian pada masyarakat ini. Ketua kelompok Tani Penggarap (Bapak Junaedi Ginting) dan anggota petani penggarap yang telah berpartisipasi selama kegiatan pengabdian ini dilakukan.

\section{DAFTAR PUSTAKA}

Nasution, D.A., Erlina, \& Muda, S. (2020). Dampak Pandemi COVID-19 terhadap Perekonomian Indonesia. Jurnal Benefita, 5(2),212.

Adi, A. P. (2020). Krisis Pangan dan Pandemi Covid 19. Bogor Agricultural University.

Hardjowigeno, S., \& Rayes M.L. (2005). Tanah Sawah, Karakteristik, Kondisi, dan Permasalahan Tanah Sawah di Indonesia. Bayumedia Publishing. Malang.

Indraningsih, K. C. (2018). Strategi Diseminasi Inovasi Pertanian dalam Mendukung Pembangunan Pertanian. Forum penelitian Agro Ekonomi, 35,107. 